\title{
Teaching theology at African public universities as decolonisation through education and contextualisation
}

\begin{tabular}{|c|c|}
\hline \multicolumn{2}{|c|}{$\begin{array}{l}\text { Authors: } \\
\text { Johan Buitendag }^{1} \text { (D) } \\
\text { Corneliu C. Simut }^{2} \text { (D) }\end{array}$} \\
\hline \multicolumn{2}{|c|}{$\begin{array}{l}\text { Affiliations: } \\
{ }^{1} \text { Faculty of Theology, } \\
\text { University of Pretoria, } \\
\text { South Africa }\end{array}$} \\
\hline \multicolumn{2}{|c|}{$\begin{array}{l}{ }^{2} \text { Historical and Systematic } \\
\text { Theology, Emanuel } \\
\text { University, Romania }\end{array}$} \\
\hline \multicolumn{2}{|c|}{$\begin{array}{l}\text { Research Project Registration: } \\
\text { Project Leader: J. Buitendag } \\
\text { Project Number: } 02402343\end{array}$} \\
\hline \multicolumn{2}{|c|}{$\begin{array}{l}\text { Description: } \\
\text { This research is part of the } \\
\text { project, 'University, Education } \\
\text { and Theology', directed by } \\
\text { Prof. Dr Johan Buitendag, } \\
\text { Department Dogmatics and } \\
\text { Christian Ethics, Faculty of } \\
\text { Theology, University of } \\
\text { Pretoria. }\end{array}$} \\
\hline \multicolumn{2}{|c|}{$\begin{array}{l}\text { Corresponding author: } \\
\text { Johan Buitendag, } \\
\text { johan.buitendag@up.ac.za }\end{array}$} \\
\hline \multicolumn{2}{|c|}{$\begin{array}{l}\text { Received: } 06 \text { Sept. } 2017 \\
\text { Accepted: } 08 \text { Sept. } 2017 \\
\text { Published: } 24 \text { Oct. } 2017\end{array}$} \\
\hline \multicolumn{2}{|c|}{$\begin{array}{l}\text { How to cite this article: } \\
\text { Buitendag, J. \& Simut, C.C., } \\
\text { 2017, 'Teaching theology at } \\
\text { African public universities as } \\
\text { decolonisation through } \\
\text { education and } \\
\text { contextualisation', HTS } \\
\text { Teologiese Studies/ } \\
\text { Theological Studies 73(1), } \\
\text { a4806. https://doi.org/ } \\
\text { 10.4102/hts.v73i1.4806 }\end{array}$} \\
\hline \multicolumn{2}{|c|}{$\begin{array}{l}\text { Copyright: } \\
\text { (C) 2017. The Authors } \\
\text { Licensee: AOSIS. This } \\
\text { is licensed under the } \\
\text { Creative Commons } \\
\text { Attribution License. }\end{array}$} \\
\hline \multirow[b]{2}{*}{ 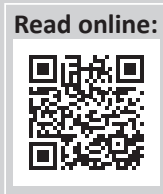 } & \\
\hline & $\begin{array}{l}\text { Scan this QR } \\
\text { code with your } \\
\text { smart phone or } \\
\text { mobile device } \\
\text { to read online. }\end{array}$ \\
\hline
\end{tabular}

This article is an attempt to provide a systematic and integrative picture of the main contributions presented at the colloquium which addressed the current state of theological education, proposals for the basic values to be laid as foundation for a new theological curriculum and concrete attempts to build such a curriculum in South Africa, the African continent and especially at the University of Pretoria with a particular stress on decolonisation as contextualisation. In dealing with these aspects, the article focuses on whether or not theology as an academic field has a future in university and society by implementing a concrete programme of decolonisation which is adapted - by means of education - to the specifics of various local contexts including those in Africa. If the answer to this question is positive - and the colloquium contributors, as well as the authors, of this article do believe to be so - then one must find out how theology should be done in the university, how theology should work in society and what (kind of) theology should be taught in the university so that its impact in society is continuously transformative and permanently relevant to human life and human existence in Africa and throughout the world.

\section{Introduction}

In order for Africa to rectify the damages of its colonial past and also have a chance at long-lasting results, any programme of decolonisation must be approached contextually in keeping with local needs and problems. For this to happen, however, decolonisation must become a reality that is constantly fuelled intellectually and then unceasingly fostered practically in such a way that continuity, durability and permanence turn into its most valued assets. Nothing of the sort can be achieved without education and particularly without higher education and the university system in general. Moreover, with particular reference to Africa, if universities are not focused on solving the problems of the African continent, decolonisation is already a wasted attempt to improve people's lives. Such improvement must be based on a specifically African consciousness - or a valid Africanness - which is permanently coupled with what professor James K. Mashabela from the University of South Africa calls 'community development' (Mashabela 2017:4).

As David F. Ford, Regius Professor of Divinity (Emeritus) at the University of Cambridge and honorary guest speaker at the banquet following the July 29 colloquium, noted in his speech, this simply means that theology has a responsibility not only in the university but also in the world and in the African context, namely to support and achieve 'life in its fullness' ${ }^{1}$ (Ford 2017:6) for 'the common good of society, local, national, and global' (Ford 2017:4). In the university and beyond it, theology must watch over all kinds of faiths in order to educate as many people as possible regarding 'inadequate public understanding of faith' which Ford calls 'foolish', 'dangerous' and 'ignorant'. In higher education, theology must seek to improve human life in all its forms virtually everywhere in the world by providing people with trustworthy comprehension of belief(s) - in Ford's (2017) words, in a public university theology must look for:

wise, more intelligent, and more responsible faith and belief, and wiser, more intelligent, and more responsible understanding of faith and belief, all for the sake of the flourishing of a healthily plural world. (p. 4)

Thus, a genuine programme of decolonisation cannot be conducted without university education and a vivid preoccupation to improve the lives of people living in local communities in the hope that as many such communities as possible throughout the African continent will benefit from these theoretical and practical endeavours. Nothing can be put into motion, however, without 
a re-formed tertiary education curriculum which, in order for it to work effectively for decolonisation through education in specific contexts, will have to be reconstructed, re-examined, reinterpreted and reconsidered (Mashabela 2017:3). This means that theological education is for everybody: religious or non-religious, clergy or laity, specialists or non-specialists because in order for it to work at all decolonisation must not only be aimed at everybody but must also be performed - if not by everybody - then at least by the vast majority which is in fact, to quote John D. Hargreaves, the 'underprivileged African majority' (Hargreaves 1996:e-book). These days though theology is not ranked among the preferred fields of study in universities so before any attempt to define decolonisation for the benefit of local contexts throughout Africa, one needs to assess whether theological education is feasible in tertiary institutions of learning as well as whether there is a future for theology in African universities - or even globally for that matter.

\section{Is there a future for theology?}

In a time of extreme secularism and unprecedented development of science, one may rightfully ask whether there is a future for theology. A science - and for some not even that much - which entertains a discourse about God in an age of scientific discoveries of all sorts and in all fields, God shrinks more and more from the traditional image of a transcendent and metaphysical entity with personal qualities to a mere idea that shapes morality or other aspects of life. When placed against raw science at its best, even this idea of God appears to be too much to believe in so it is perhaps inevitable for more and more people not only to think of giving up this idea entirely but also to move away from theology and let it meet its natural demise especially when as Gavid D'Costa notices - discourses about God take the shape of 'secularized forms of theology' (D'Costa 2005:ix). These are the times in which we live in the first decades of the 21st century and when such perspectives on theology remain no longer confined to popular convictions but are appropriated by intellectual elites, the issue of whether theology has or should have a place in the university (or even in any educational system for that matter) becomes a practical question especially in the African context where pressing matters such as decolonisation and/or through education require particular attention because, to quote Edward Shizha, such efforts need to 'reflect Africa's social and cultural realities' (Shizha 2012:171). Everything in this world has a certain financial value, not only that but also finances are involved in keeping, maintaining and developing everything. Theology is no exception to this rule and its presence in the university or elsewhere in the educational system is, in the end, a matter of financial resources. To put it bluntly: should theology be financed in order to be kept within universities or not? In Africa and throughout the world?

In less economic terms, the question becomes philosophically even clearer: does theology have a future in our age of science and technology? Professor Marcel Barnard from the Protestant Theological University of Amsterdam in the
Netherlands does not seek to answer this question in affirmative or negative terms but he attempts to shift one's attention from economy and philosophy in order to focus it on geography. As such, his geographic choice is the African continent where the Christian religion not only has over 800 million adherents, but their number is likely to increase in the near future. Thus, Barnard is of the opinion that if predictions are true, then African Christians will most likely grow to over 1 billion by 2050 in sub-Saharan Africa (Barnard 2017:5). Such statistics almost automatically provide an answer to the question of whether theology has a future or not. Even focusing exclusively on Africa - although other geographical regions such as South America or Eastern Asia have experienced similar growing tendencies - it goes without saying that theology not only has a future but it must remain and develop in universities and other educational institutions because it needs to nurture this unprecedented growth of the Christian religion. Given this particular situation, erasing theology from the academy can be not only academically irresponsible because the practical side of theology has been developing in such an alert pace but also socially problematic because any fulminant progress needs to be closely monitored by specialised people who understand the reality of the theoretical and practical sides of theology and are professionally apt to implement decolonisation programmes through education in specific African contexts. This is needed even more when one thinks of the African continent as a plurality of extremely diverse communities with variegated religious beliefs; such 'pluralist societies' - as David F. Ford is very clear in affirming - 'are ... stakeholders in the future of theology' (Ford 2011:148). If this is true, then the future of theology and Africa and throughout the world can be considered in rather optimistic terms.

Nevertheless, it is not only geography which provides an affirmative answer to the question of whether theology has a future; history does the same. Professor Fanie Snyman from the University of the Free State in South Africa underscores the fact that history is a key aspect of understanding not only the role of theology but also the way it can assist in the development of society. Thus, Snyman points out that every human being is a 'product of history' (Snyman 2017:63), a Marxist idea which - as Erich Fromm points out - underlines the human being's creative capacities in the natural world (Fromm 2013:24). One cannot detach oneself from history and from its concrete reality that means that because theology has been developing within history, then its reality and even its theoretical perspective on reality - theology in the academy - cannot and should not be ignored. History, however, is not only complex in terms of chronology; it is complex also in terms of politics and in the particular case of Africa the reality of the Apartheid cannot and should not be ignored either. What Snyman is trying to say has to do with the fact that history must be faced boldly and theology can facilitate a better understanding of history so that society develops progressively and does not regress into past mistakes. In dealing with Apartheid realities, theology in Africa has been dealing with the issue of decolonisation for decades in an attempt to provide the 
continent and local communities with fresh indigenous perspectives. The hard fact that theology in Africa is historically connected to theology in Europe may present a problem to the very concept of decolonisation - which in some quarters means de-Europeanisation or deWesternisation; this is why Snyman proposes the use of the term contextualisation - hence decolonisation through contextualisation. Theology must remain in universities because it can serve people in local communities; theology must not only be aware of the needs of local communities, but it must also render proper service to those communities at every possible level: social, economic, academic and so on (Snyman 2017:62).

It appears though that not only geography and history respond positively to the question of the future of theology, but religion itself comes up with an answer which is even more straightforward. Thus, for Professor Joseph Mante from Trinity Theological Seminary in Ghana the very reality of life is sufficient proof of the need to have theology developed, nurtured and supported not only in universities but literally everywhere through active decolonisation and realistic education. As far as Mante is concerned, real life is 'seriously religious' because even secularisation is a 'metaphysical assumption' (Mante 2017:31-32). Human beings have always been in search of scientific 'proof', but the concept of proof is not exclusively scientific. Proof of a very different sort is provided by religion and specifically by theology because as argued by Franz Overbeck, Friedrich Nietzsche's longlasting friend, in the 19th century - theological proof is not concerned primarily with science (Overbeck 2002 [1873]:76). Thus in a world where proof has so many facets, theology appears to have secured its rightful place in the academy, in the university and virtually in any quarter of contemporary societies. This appears to be a fact irrespective of geography and history; moreover, theology needs to be present especially in places where the development of the Christian religion is more than evident, such as Africa.

\section{How should theology be done?}

If there is indeed a future for theology in the world, then there is most certainly a place for theology in the university, but when theology is performed in an academic context, we are automatically faced with the question of method, namely how should we do theology. A starting point may be identified in Snyman's idea of decolonisation through contextualisation (Snyman 2017:62), which focuses on doing theology in such a way that it helps the local community based on reliable education. When it comes to Africa and especially to its sub-Saharan region, one will immediately take notice of the fact that the common denominator of the populations living in this geographic area is poverty, which as revealed by Philip Kennedy - has emerged as a major preoccupation of contemporary theology (Kennedy 2006:e-book). Thus, as we start considering how we should do theology, it would not be illogical to consider the possibility that theology should address not only the reality but also the idea of poverty. As one may imagine, poverty is only a rather loose term that describes the lack of the most common means for one's existence in the world, but in fact it encompasses a wide range of social problems dealing with conflict, politics, economics and administration as confined to a certain region. This is why Patrick Hornbeck from Fordham University in New York resorts to Ignacio Ellacuría's idea of 'proyecto social', which he originally applied to the university (Hornbeck 2017:27), but by extension it fits theology rather perfectly.

As Hornbeck shows, in Ellacuría's thought, the university as social project should produce a deep impact in society and particularly in specific communities. Universities can provide not only social transformation but also intellectual enlightenment, which both radically alter the very fibre of societies and communities - in the words of Alain Touraine, 'the university reproduces society, it produces for society, and it serves to transform society' (Touraine [1997] 1974:xxi). Hornbeck delves deeper into Ellacuría's argument, which deals not only with state universities but also with Christian universities; as such, these institutions of higher education have the chance to apply the teachings of the Christian Gospel to those in need, especially to those who lack the basic means to lead a decent existence in the world (Hornbeck 2017:28). Thus, the poor are targeted by theology and this can work not only in Ellacuría's Latin America, but also anywhere else in the world as well as in Africa. Thus, because theology deals with such a chronic social problem like poverty one may correctly ask why the task of theology should not be expanded to all universities as means of decolonisation through contextualisation and education. In concrete terms, state-funded universities which already have faculties of theology not only can but also should focus on supporting theology for the sake of alleviating the problem of poverty. The public universities which have no faculty of theology may well consider founding one for the sake of the very same purpose: the actual engagement with the reality of poverty. In dealing with poverty by means of theology, public universities have the unique chance to achieve social transformation and in so doing, to also promote an active programme of social improvement for the sake of whole communities (Hornbeck 2017:29).

Theology, however, can and perhaps should be taken a step further, namely beyond the boundaries of the Christian religion. This is why Professor Ruard Ganzevoort from the Free University of Amsterdam in the Netherlands suggests that social transformation as envisaged by Christian and public universities should first and foremost clarify the very notion of religion. In the 21st century when globalisation is a reality and connectivity among societies is unprecedented, theology should no longer be restricted to the Western world and Christianity. On the contrary, theology should be shifted and reoriented towards the world's entire range of religious faiths and communities in which case theology becomes synonymous to religious studies and turns into an instrument for the study of the human being and human existence in the world (Ganzevoort 2017:22-23). 
When this happens, namely when theology becomes a religious study focusing on the study of humanity, one may correctly conclude that theology also turns into an engaged enterprise, and effort which although carried out in the academy is always targeted at societies and communities because, according to David Baker, universities provide humanity with the extremely important service of 'creating meaning throughout society' (Baker 2014:293). Theology therefore, must never remain a preoccupation of the academic world, but it must instead become a public effort to engage in society as widely as possible, which makes decolonising efforts possible through the provision of proper education in specific contexts. As religious study in the university, theology must never refrain from addressing all the issues of society, no matter how difficult and irrespective of consequences. Ganzevoort insists that the main task of theology is to push faith(s) towards seeking understanding, so the human being's innermost personal convictions must be coupled with society's latest scientific developments for the sake of achieving positive social transformation (Ganzevoort 2017:24-25).

When theology addresses the core problems of society, the academic study of theology becomes not only engaged with 'everyday religion' but also preoccupied to develop as 'public theology'. These insights are proposed by Professor Christian Danz from the University of Vienna in Austria who also recommends that theology should be performed for the sake of helping society understand its fabric and problems. Thus, according to Danz, theology deals with interpretation so it is in this capacity that theology can provide communities with valid solutions to the problems of contemporary culture throughout the world (Danz 2017:16). In the university, theology can and should be allowed and even supported to work alongside philosophy, the philosophy of religion, and social ethics because what theology does in the academy is to deal with symbols such as God, Christ and Spirit in order to interpret them for the whole society by means of what Roger Haight calls 'symbolic communication' (Haight 1999:209). Theology puts together history and philosophy in an effort to interpret the most basic ideas of humanity, such as God, for the benefit of the whole society and particular communities which can reach not only a genuine level of self-understanding (or sensible decolonisation through education in the African context), but also a decent capacity to provide theories about different stages of human development (Danz 2017:17). All in all, theology must be done for the sake of the whole society as an attempt to study the whole range of human religions in order to identify, engage and solve humanity's most pressing problems.

\section{How should theology work?}

Snyman's idea that theology should work contextually (Snyman 2017:62) is backed by Professor Hendrik Bosman from the University of Stellenbosch in South Africa who believes that theology should deal with as many aspects of human society as possible, including economic, environmental, intellectual, legal, political and social issues
(Bosman 2017:10). Once this aspect has been clarified, namely, that we should do theology for the benefit of the entire society based on a realistic programme of decolonisation through contextualisation, the question which one must answer is how theology works in society by means of university education. Are there any specific facets which academic theology must deal with in order to engage in social life? Bosman attempts to provide an answer as he identifies three such elements that explain how theology can and should work not only in the theoretical environment of the university but also in the practical life of society. Thus, as far as Bosman is concerned, theology must work as rationality, pedagogy and ethos. As rationality, theology must work constantly to implement human reason in areas such as hermeneutics, assessment and action because, as James $\mathrm{W}$. McClendon convincingly argues, theology is not only a(n) (academic) discipline but also a (practical) métier, a profession in its own right (McClendon 2002:38). In other words, theology must help people interpret the world, evaluate its problems and act upon them in order to improve human life. Rationality helps theology move beyond Christianity into the realm of world religions so that not only certain communities benefit from its insights, but the whole world lives to see its positive influence. However, in order for theology to spread its beneficial influence across the world, universities need to make sure that theology is being taught in the spirit of genuine pedagogy for the benefit of humanity not of political agendas and ideologies. This goal, however, cannot be achieved unless the idea of ethos is implemented in dealing with issues such as 'class, gender and race' throughout the world without any sort of 'ideologised prejudice' (Bosman 2017:11-12).

Theology is all about interpretation so it cannot work properly without hermeneutics. In its capacity as science of textual interpretation, hermeneutics is the foundation of theological inquiry precisely because, according to Thomas G. Guarino, hermeneutics provides theology with 'enduring meanings' (Guarino 2005:171). Consequently, one must define the essence and the limits of hermeneutics if theology is to work properly and prove its effectiveness in the practical and social life of all communities throughout the world and especially in Africa, where theology can work as an educational programme of decolonisation. A useful attempt to define theological hermeneutics was undertaken by Marcel Barnard, who sees hermeneutics as being characterised by three fundamental characteristics: freedom, criticism and commitment. As a free discourse, theological hermeneutics must never differentiate between 'traditions, convictions, beliefs and practices' because it must evaluate all as objectively as possible. As a critical discourse, theological hermeneutics must be equally fair in assessing all 'traditions, convictions, beliefs and practices' according to the same standard so that all communities should benefit from its interpretation. As a committed discourse, theological hermeneutics must be constantly and unceasingly dedicated to the improvement of human life in all possible human contexts (Barnard 2017:5-6). 
Consequently, the idea which is slightly taking shape has to do with the fact that because theology is concerned with all human beings in all possible contexts, theology appears to be the common denominator of all societies because, in the words of Lieven Boeve, 'theology finds itself at the crossroads of academy, church, and society' (Boeve 2016:54). Theology is not only supposed to engage all societies, but it must also do this as pragmatically as possible; this is why Ruard Ganzevoort writes about the necessity to find a 'common language' among all human societies and communities (Ganzevoort 2017:24).

Theology can function as common language among all human beings because it has the potential to transcend the boundaries of the Christian religion into the realm of world religions in its capacity as interpretation tool for human beings and human life - in the specific context of the African continent, academic theology can find a useful expression as pedagogical decolonisation if kept and promoted within and throughout universities. Theology thus works not only as integrative principle for human life but also as integrative science because it not only connects all scientific fields by its interpretative prerogatives, but it also tackles humanity's most pressing problems such as the eradication of poverty, the countering of climate change, the reduction of gender inequality and the fostering of peace and justice (Ganzevoort 2017:25).

In this respect, in a public university environment, theology becomes the property of the entire humanity; it is no longer as Ganzevoort puts it - 'the prerogative of the church' (Ganzevoort 2017:24), but a highly precious possession of humanity in general, irrespective of religion or anything else for that matter. As an academic discipline in public universities, theology must deal with literally all the issues of interest in contemporary times. This is why theology must acquire a multifaceted perspective in attempting to provide answers to politics, public life, feminist issues, black ideologies and even the extremely complex theories about human sexuality (Ganzevoort 2017:24).

When Ganzevoort writes that theology is no longer 'the prerogative of the church' and in so doing he actually turns theology into the property of the entire human race, he is backed by Hornbeck's conviction that public universities academic theology included - is the 'common property of us all' (Hornbeck 2017:29). In this particular respect, theology is fundamentally educational and the role of education in transforming the world can never be overestimated especially since the dawn of modernity when, as one can read in Augusta Dimou, 'the state challenged the prerogative of the church over instruction' (Dimou 2009:17). By turning this argument on its head, one must realise that in our times there must be no education, especially public or state education without theology in which case, with regard to Africa, there is no realistic decolonisation without education. Even more so, genuine education will never lose sight of theology as interpretative instrument for the promotion of 'the public good' as well as for the 'actualisation of human potential'
(Hornbeck 2017:29). The question regarding how theology should work now has a concrete answer: theology should work as education and when professed in academic quarters such as public universities, theology becomes a sine qua non means not only for a better interpretation of the world and human life but also for the actual improvement of the world and human life. Regardless of whether theology is carried out in academic contexts or practical situations, its essential focus is the fundamental transformation of human society and human life by concrete attempts to implement social measures aimed at the eradication of humanity's most shameful ideologies such as 'racism, slavery and segregation'. In a word, theology is supposed to transform the world by actively and decisively fighting oppression in all its forms (Hornbeck 2017:29, 28) by constantly providing quality and excellence in education, especially in public universities.

\section{What theology should be taught?}

So far it has been shown that theology must go beyond the boundaries of Christianity into the realm of world religions and then it should act as an interpretative instrument which transforms the world by attempting to solve humanity's most pressing problems. In the words of Johann-Albrech Meylahn, a professor at the University of Pretoria in South Africa, the kind of theology which should be taught in universities and is capable of producing world transformation is the one that acts like logos or light, a theology which 'illuminates' the world (Meylahn 2017:37) and can be based, as proved by Douglas Harink, on one of the classical images of traditional Christian theology, namely the transfiguration of Jesus Christ (Harink 2009:158). This specific kind of theology is an endeavour, which creates perspectives, or ideas whereby one can see the world in a new light. This is the kind of theology, which possesses the capacity to change the world by virtue of its inner potentiality to shed light, a new light onto the world so that, as far as the African continent is concerned, decolonisation becomes possible and feasible through education. This kind of theology is innovative and inspiring, but this specific type of theology - Meylahn argues - can only be devised, nurtured and professed in 'just universities' which function within 'vibrant democracies' (Meylahn 2017:38). Thus, just universities and vibrant democracies are concepts which become intertwined in the world mostly because neither can exist without the other.

A just university is an institution which not only has the capacity to harbour many constructive perspectives but also enacts that capacity in a way which inspires positive change. A just university, as conveyed by its very own name, is a realm which provides the world with multifaceted possibilities or, in Meylahn's words, it works based on a curriculum which has the potential 'to create spaces for different worlds' (Meylahn 2017:38). Such an institution cannot function without a proper context which allows for unbridled thinking, critical reflection and multicultural epistemologies.

A theology which has the capacity to transform the entire world, not just parts of the world, needs to be free when it 
comes to the investigation and circulation of ideas; then it needs to be allowed to evaluate all ideas in a critical way because, in the words of Clive Marsh, 'theology has a critical task beyond a religious tradition itself' (Marsh 2008:19). At the same time, this kind of theology must always learn to address specifically local situations and contexts based on methodologies that promote the inclusion of as many human realities as possible so that in Africa university education truly becomes an instrument of effective decolonisation. This kind of theology must produce equality and openness; ideas from all over the world and from the entire spectrum of human thinking must be accommodated as part of the same academic endeavour, which must constantly and incessantly remain open to new ideas. There should be no limits in dealing with ideas within theology - everything is welcome for assessment and nothing is left aside to escape criticism because theology is for the people and people live all over the world in 'multi-cultural' and 'multiple-world contexts' (Meylahn 2017:39).

Even if it has been argued that the theology of the 21st century is no longer the prerogative of the church (Ganzevoort 2017:24), but an enterprise which must encompass the complete spectre of world religions, a transformative theology which aims at changing the world for the better must never lose sight of the church and specifically of all Christian churches, which, alongside universities, can turn into efficient decolonising factors. While the distinction between Christianity and world religions must disappear in the academy for the sake of an inclusive and all-embracing theology, the reality of all Christian churches and their specific theologies must never be ignored or, ever worse, forgotten.

All Christian beliefs and practices must be assessed critically alongside the beliefs of other religions and traditions; the main religious traditions and their subordinate factions must all be included in the effort of today's theology to transform the entire world and its specific contexts because - an evident argument in Bruce J. Nichols' work - the theology's task of critical evaluation must always be done by contextualisation (Nichols 2003 [1979]:24-25). Nevertheless, while all religions are promoted equally by this new and transformative theology, the traditions which make up the world's religions must never be underestimated. This kind of theology must be constantly inclusive and always aware of the entire puzzle of human religions; in the university of the 21st century, theology must be professed in such a way that all viewpoints are accommodated for serious evaluation and critical assessment. In the words of Marcel Barnard, 'students and scholars are invited to introduce their beliefs and practices and discuss them critically with others' (Barnard 2017:8). Such an approach is nothing short of an 'ideal', but despite the utopian nature of this very concept, the idea of having such a theology promoted and taught in contemporary universities can at least be thought as possible; it can be implemented in a concrete way throughout the world and specifically in Africa through educational decolonisation.
This means, quite simply, that all perspectives are permitted and all views are embraced as informative for students irrespective of the preferences of educators if any decolonising effort in Africa is to be successful in the long run. In the specific case of the Christian religion, as taught in public universities, a transformative theology should include both traditionalism and liberalism, both classical and secular approaches to Christianity's doctrines and practices, rather than 'shifts' from 'liberalism to traditionalism' or vice versa, as highlighted by Olli-Pekka Vainio ([2010] 2016:1). Since theology is never abstract because it discusses and analyses doctrines which are professed in the real contexts of specific churches, those who study theology must be exposed to all the facets of religion, regardless of whether it is Christian or not as well as without preference when it comes to the interpretation of theological concepts or practical realities. Theology, therefore, must never be pigeonholed - it must never be placed into segregated boxes which could be selectively given to students.

Thus, it is obvious why Corneliu Simuț, senior postdoctoral research fellow at the University of Pretoria in South Africa, writes that theology must never be divided for the sake of science; no aspect of theology and no interpretation of theology should ever be excluded or discarded on the grounds of being less scientific or less credible from a scientific perspective (Simuț 2017:56-57). The study of theology in the public universities of the 21st century - in Africa or elsewhere in the world for that matter - must offer an image of theology which is as encompassing as possible because the world cannot be changed nor can it be transformed without those who actually study theology. These in turn need to be made aware of the multifaceted realities of religion, Christian or not, scientific or not, convincing or not, credible or not, because transformation is impossible without proper knowledge and serious investigation of all religious phenomena.

\section{Concluding remarks: A possible way forward}

All these proposals to keep theology in the university as an interpretative tool for human life and existence in the world with the specific purpose of improving the situation of every human being in its specific social context cannot take shape unless universities make sure that they have a concrete curriculum, which not only includes theology among the humanistic sciences but also promotes academic theology as a vital field of teaching and research. Such an approach is compulsory because these days - as strongly underlined by Wolfram Weiße - education itself is a crucial domain, which deals with religion and religiosity (Weiße 2008:349). This is why Professor Johan Buitendag, Dean of the Faculty of Theology within the University of Pretoria in South Africa, presented his academic staff with a formal Draft Framework Document (authored by a team of university officials) for reimagining tertiary education curriculum in the field of theology. The document itself is the result of several meetings among the members of the teaching staff of the Faculty of Theology as 
well as between them and their students. Such meetings were initiated and held with the intention to discuss the possibility of having a transformative theological curriculum because even after over 20 years of democracy, the general situation in South Africa is still characterised by 'exclusion, marginalization and social injustice' (Buitendag 2017:65).

The purpose of theological education should be to promote the most fundamental of human values such as 'dignity, equality, human rights and freedom' (Buitendag 2017:65). These, however, will never be fully implemented unless education is pushed forward based on a proper curriculum that is sensitive not only to the contents of theology itself as a field of teaching and research but also to the general situation of the immediate social, political, economic and cultural contexts. Because contexts are never the same even though they may appear to be so, university education and the promotion of theology as interpretative tool for the transformation of society must take into account not only what happens in tertiary education throughout the world but also - and vitally so - what is going on in the specific context which a certain higher education institution is addressing by training the majority of students who actually live there but always in connection with the whole world. Within the same lines, Joseph E. Bush notices that contextualised theology is unavoidable today simply because globalisation involves 'shared praxis in society' (Bush 2016:114). According to the Draft Framework Document, each context has 'local knowledges and objectives', and these must be considered important for the betterment of the life of the people in the region although the kind of education and research produced by the local university should be 'cutting edge ... with a global reach'. This clearly presupposes the existence of a 'larger vision' which is shared not only by the top management university team but also by the academic staff and the students (Buitendag 2017:66).

Any university which is set to follow these objectives will have to promote 'critical inquiry, thinking and democratic public engagement' (Buitendag 2017:66). In other words, a lot of intellectual efforts will have to be poured in training both the members of the academic staff and the students to investigate, research and evaluate everything in a critical way, then in finding meaningful ways to transfer the resulting knowledge into the public life of the local context. Whatever happens in the university will have to find a way to reach as well as impact public life with the final purpose of improving the individual lives of as many people living there as possible. These intentions, however, cannot be achieved unless the education curriculum in all faculties - and especially in the faculty of theology as promoter of interpretative social instruments - is dramatically reassessed, changed and then carefully as well as diligently implemented with consideration, competence and continuity. A new, innovative and transformative curriculum though will have to be capable of transforming not only education within the university itself but also human life throughout the local context and beyond by what Ivor Davidson calls 'practical, public, contextual, conversational or transformational theology' (Davidson 2015:73). In order for this to happen, however, this particular curriculum - and this is aimed particularly at theological faculties in public universities - will have to include crucial characteristics such as 'responsiveness to the social context, epistemological diversity, renewal of pedagogy and classroom practices' and 'an institutional culture of openness and critical reflection', all aimed at the sole purpose to improve human life (Buitendag 2017:66).

In order for such a curriculum to take shape and theology to be actively promoted within these lines, the very first persons who must put considerable effort into turning these ideas into reality are the members of the academic staff of theological faculties. Regardless of whether they work in teaching or research, or both, they must all reflect not only upon how such a curriculum can look like but also upon how the new and transformative curriculum can avoid 'any limitations, gaps and shortcomings' present in the current curriculum (Buitendag 2017:71-72). Nevertheless, such efforts will have to go beyond the theological curriculum itself into the 'blind spots' of each theological discipline, which will have to be identified and rectified in such a way that theology does in the end become transformative of human life and human existence in the world. This conviction echoes the argument of George M. Newlands who defends theology and its transformative powers because 'God has consequences for all human life' (Newlands 2006:186). The profile of the theology graduate will then have to be taken into account and also how the knowledge promoted by the new curriculum can be effectively communicated and transferred into theology students. As such, it is imperative that they should be seen not only as promoters of the curriculum's most basic values but also as agents of change whenever they implement these values into society by active involvement based on their trans-formed and re-formed theological education (Buitendag 2017:72). One can only hope as well as well as act decisively towards meeting these ends so that theology does become an instrument of social transformation for the significant improvement of human life throughout the world in as many local contexts as possible.

\section{Acknowledgements Competing interests}

The authors declare that they have no financial or personal relationships which may have inappropriately influenced them in writing this article.

\section{Authors' contributions}

J.B. and C.C.S. equally contributed to the research and writing of this article.

\section{References}

Baker, D., 2014, The schooled society: The educational transformation of global culture, Stanford University Press, Stanford, CA.

Barnard, M., 2017, 'A felicitation to the Faculty of Theology in Pretoria', in J. Buitendag (ed.), Centenary celebrations colloquium - Reimagining curricula for a just university in a vibrant democracy: Carrying the conversation forward, pp. 4-8, Faculty of Theology, University of Pretoria, Pretoria.

Boeve, L., 2016, Theology at the crossroads of university, church, and society: Dialogue, difference, and catholic identity, Bloomsbury T\&T Clark, London. 
Bosman, H., 2017, 'Curriculum transformation in a Faculty of Theology', in J. Buitendag (ed.), Centenary celebrations colloquium - Reimagining curricula for a just university in a vibrant democracy: Carrying the conversation forward, pp. 9-13, university in a vibrant democracy: Carrying the con
Faculty of Theology, University of Pretoria, Pretoria.

Buitendag, J., 2017, 'Draft framework document', in J. Buitendag (ed.), Centenary celebrations colloquium - Reimagining curricula for a just university in a vibrant democracy: Carrying the conversation forward, pp. 65-72, Faculty of Theology, democracy: Carrying the conversa
University of Pretoria, Pretoria.

Bush, J.E., 2016, Practical theology in church and society, Wipf and Stock Publishers, Eugene, OR., (Cascade Books).

Danz, C., 2017, 'The future of theology', in J. Buitendag (ed.), Centenary celebrations colloquium - Reimagining curricula for a just university in a vibrant democracy: Carrying the conversation forward, pp. 14-18, Faculty of Theology, University of Pretoria, Pretoria.

Davidson, I., 2015, 'Divine sufficiency: Theology in the presence of God', in R.D. Nelson, D. Sarisky \& J. Stratis (eds.), Theological theology, pp. 55-74, Bloomsbury T\&T Clark, London.

D'Costa, G., 2005, Theology in the public square: Church, academy, and nation Blackwell, Oxford.

Dimou, A., 2009, Entangled paths towards modernity: Contextualizing socialism and nationalism in the Balkans, Central European University Press, Budapest.

Ford, D.F., 2011, The future of Christian theology, Wiley-Blackwell, Oxford.

Ford, D.F., 2017, 'The future of theology at a public university, An address by Professor David F. Ford OBE, University of Cambridge', viewed 06 September 2017, from http://www.up.ac.za/en/news/post_2531066-celebrating-a-century-of-academicexcellence

Fromm, E., 2013, Erich Fromm and Karl Marx: Marx's concept of man. Including economic and philosophical manuscripts, Bloomsbury, London.

Ganzevoort, R.R., 2017, 'Engaged scholarship', in J. Buitendag (ed.), Centenary celebrations colloquium - Reimagining curricula for a just university in a vibran democracy: Carrying the conversation forward, pp. 19-25, Faculty of Theology, University of Pretoria, Pretoria.

Guarino, T.G., 2005, Foundations of systematic theology, T\&T Clark, London.

Haight, R., 1999, Jesus, symbol of God, Orbis Books, Maryknoll, NY.

Hargreaves, J.D., 1996, Decolonization in Africa, Taylor and Francis, London.

Harink, D., 2009, 1 \& 2 Peter, Brazos Press/Baker Publishing Group, Grand Rapids, MI.

Hornbeck, J.P., II, 2017, 'Education for justice', in J. Buitendag (ed.), Centenary celebrations colloquium - Reimagining curricula for a just university in a vibrant democracy: Carrying the conversation forward, pp. 26-30, Faculty of Theology, University of Pretoria, Pretoria.
Kennedy, P., 2006, A modern introduction to theology: New questions for old beliefs, I. B. Tauris, London.

Mante, J.O.Y., 2017, 'Theology in public universities in Africa', in J. Buitendag (ed.), Centenary celebrations colloquium - Reimagining curricula for a just university in a vibrant democracy: Carrying the conversation forward, pp. 31-36, Faculty of Theology, University of Pretoria, Pretoria.

Marsh, C., 2008, Theology goes to the movies: An introduction to critical Christian thinking, Routledge, London.

Mashabela, J.K., 2017, 'Africanisation as an agent of theological education in Africa' HTS Teologiese Studies/Theological Studies 73(3), a4581. https://doi.org/10.4102/ hts.v73i3.4581

McClendon, J.W., Jr., 2002, Ethics: Systematic theology, vol. 1, Abingdon Press, Nashville, TN.

Meylahn, J.-A., 2017, 'Re-imagining curricula', in J. Buitendag (ed.), Centenary celebrations colloquium - Reimagining curricula for a just university in a vibrant democracy: Carrying the conversation forward, pp. 37-41, Faculty of Theology, democracy: Carrying the conversc
University of Pretoria, Pretoria.

Newlands, G.M., 2006, Christ and human rights: The transformative engagement, Ashgate, Aldershot.

Nichols, B.J., [2003] 1979, Contextualization. A theology of gospel and culture, Regent College Publishing, Vancouver.

Overbeck, F., [2002] 1873, On the Christianity of theology, Wipf and Stock Publishers, Eugene, OR, (Pickwick Publications).

Shizha, E., 2012, 'Are we there yet? Theorizing a decolonizing science education for development in Africa', in A.A. Abdi (ed.), Decolonizing philosophies of education, pp. 163-176, Sense Publishers, Rotterdam.

Simut, C.C., 2017, 'Searching through theology', in J. Buitendag (ed.), Centenary celebrations colloquium - Reimagining curricula for a just university in a vibrant democracy: Carrying the conversation forward, pp. 42-60, Faculty of Theology, University of Pretoria, Pretoria.

Snyman, S.D., 2017, 'Decolonization and the theological curriculum', in J. Buitendag (ed.), Centenary celebrations colloquium - Reimagining curricula for a just university in a vibrant democracy: Carrying the conversation forward, pp. 61-64, university in a vibrant democracy: Carrying the conver
Faculty of Theology, University of Pretoria, Pretoria.

Touraine, A., [1997] 1974, The academic system in American society, Transaction Publishers, New Brunswick, NJ.

Vainio, O.-P., [2010] 2016, Beyond fideism: Negotiable religious identities, Routledge, London.

Weiße, W., 2008, 'Religious education in the European horizon: The significance of inter-cultural learning', in H. Streib (ed.), Lived religion: Conceptual, empirical, and practical-theological approaches, pp. 249-362, Brill, Leiden. 